\title{
Ulisses - a Odisséia de um corpo: relações entre arte e literatura
}

MÁRIO MENDES CAVALCANTE

Resumo

A pesquisa em questão pretende investigar as relações entre arte e literatura, a partir do ensaio fotográfico Ulisses - a Odisséia de um corpo, produzido por mim como trabalho de conclusão de curso de graduação. Explorando outras leituras visuais da Odisséia de Homero em diferentes meios, como o cinema e as artes plásticas, bem como outras experiências de tradução intersemiótica desenvolvidas por artistas contemporâneos, esse trabalho propõe um diálogo entre os estudos intersemióticos ou intermidiáticos, produzidos no campo da literatura comparada, a teoria e a história da arte. 